\title{
COMMENTS ON THE DISTRIBUTION OF BOTRYCHIUM LUNARIOIDES (OPHIOGLOSSACEAE) IN TEXAS
}

\author{
W.C. Holmes, T.L. Morgan, J.R. Stevens, \& R.D. Gooch \\ Department of Biology, Baylor University, Waco, Texas 76798-7388 U.S.A. \\ $\&$ \\ J.R. Singhurst \\ Wildlife Division, Texas Parks and Wildlife Department, Mexia, Texas 76667 \\ U.S.A.
}

\begin{abstract}
Botrychium lunarioides (Michx.) Sw. (Ophioglossaceae) is now known to be widespread and abundant throughout the eastern portion of Texas.
\end{abstract}

KEY WORDS: Ophioglossaceae, Botrychium, Texas, biogeography

Until recently, Botrychium lunarioides (Michx.) Sw. (Ophioglossaceae) was considered to be a species of the coastal plain of the southeastern United States whose westernmost distribution was known to extend to extreme east Texas (Thomas 1979; Thomas, et al. 1981; Wagner \& Wagner 1993). In 1996, Do, et al. reported ten additional county records in the central portion of the Post Oak Savannah of Texas, thereby extending the known distribution of the species up to $273 \mathrm{~km}$ to the west. Additional field studies during 1996 have yielded nineteen new county records for the species in Texas (Figure 1). These new reports are primarily from the Post Oak Savannah, Pineywoods, and Blackland Prairies of northeast Texas and from the southern portion of the Post Oak Savannah. The most notable occurrence of the species is at Lake Bastrop State Recreation Area, Bastrop County, about $45 \mathrm{~km}$ ESE of Austin, which extends both the western and southern known limits of the species. The present distribution confirms that the plant is much more widespread and abundant within the state than previously known and that it may be expected to occur in nearly all counties of the Pineywoods and the Post Oak Savannah. Although the habitat of the very southern portion of the Post Oak Savannah (Caldwell, Gonzalez, Guadalupe, and Wilson counties), seems to be favorable for the species, an attempt to locate it 


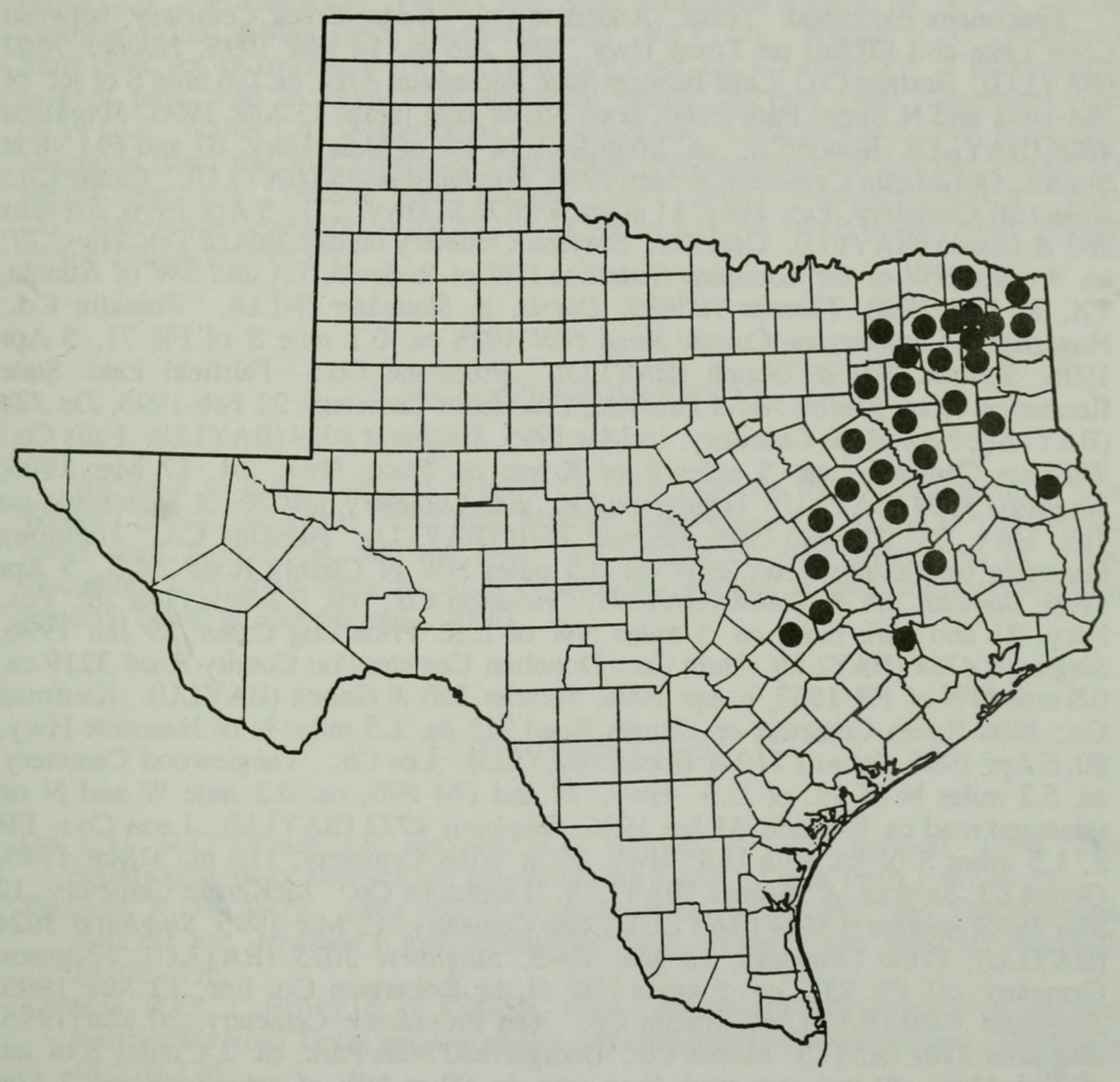

Figure 1. Documented distribution of Botrychium lunarioides in Texas. 
there was unsuccessful. This failure may be related to the extreme drought in that area in the late winter and early spring of 1996, which has been mentioned by Thomas, et al. (1981) as a factor that may cause the species to remain dormant.

Specimens Examined: Texas: Anderson Co.: Cedar Creek Cemetery, between Long Lake and Elkhart on Texas Hwy. 294, 135 m, 14 Mar 1995, Holmes 7602 (BAYLU). Bastrop Co.: Lake Bastrop State Recreation Area, ca. 0.6 mile S of jct. of FM 1441 and N Shore Park Road, lawn NE of boat ramp, 13 Mar 1996, Singhurst 4806 (BAYLU). Bowie Co.: ca. 2.6 miles E of jct. of U.S. Hwy. 67 and FM 98 at Simms, Old Martin Cemetery, 6 Mar 1996, Singhurst 4805 (BAYLU). Camp Co.: Rose Hill Cemetery, Tex. Hwy. 11 at jct. with U.S. Hwy. 271, 5 Apr 1996, Stevens 203 \& Gooch (BAYLU). Cass Co.: Smyrna Cemetery on east side of Tex. Hwy. 77 , ca. 4 miles NW of the Louisiana State line NW of Rodessa, LA and SW of Atlanta, TX, 31 Mar 1988, Thomas 103695, Dorris, \& Slaughter (NLU). Franklin Co.: Hogansport Cemetery on County Road NW $1028 \mathrm{ca}$. 0.1 mile S of FR 71, 5 Apr 1996, Stevens 200 \& Gooch (BAYLU). Freestone Co.: Fairfield Lake State Recreation Area, 6 miles NE of Fairfield, Chancellor Cemetery, 22 Feb 1995, Do 324 (BAYLU); New Hope Cemetery, 18 Mar 1995, Singhurst 3029 (BAYLU). Falls Co.: Williams Cemetery, ca. 5 miles S of Kosse on Texas Hwy. 14, 17 Mar 1995, Singhurst 3004 (BAYLU). Henderson Co.: Ash Cemetery, just SE of Murchison on Tex. Hwy. 31, 17 Mar 1995, Holmes 7610 (BAYLU). Hopkins Co.: Harmony Cemetery on County Road 2397 ca. 0.5 miles NW of County Road 2403, 5 Apr 1996, Stevens 206 \& Gooch (BAYLU). Houston Co.: ca. 0.2 mile N of jet. Tex. Hwy. 21 and park road, ca. 5 miles NW of L.R. Price Log Cabin; 29 Jan 1996, Singhurst 4734 (BAYLU). Hunt Co.: Donelton Cemetery on County Road 3219 ca. 0.8 mile NW of FR 1567, 6 Apr 1996, Stevens 208 \& Gooch (BAYLU). Kaufman Co.: New Salem Cemetery on County Road 315 ca. 1.5 miles N of Interstate Hwy. 20, 6 Apr 1996, Stevens 210 \& Gooch (BAYLU). Lee Co.: Tanglewood Cemetery, ca. 5.2 miles $\mathrm{N}$ of jet. of U.S. Hwy. 77 and FM 696, ca. 0.2 mile W and N on unnamed road ca. 0.4 mile, 31 Jan 1996, Singhurst 4773 (BAYLU). Leon Co.: FR 3, 1.5 miles S of jct. with U.S. Hwy. 79 at Winn Cemetery, 110 m, 3 Mar 1995, Gooch 63, Stevens, \& Holmes (BAYLU). Limestone Co.: McKenzie Cemetery, 12 Mar 1995, Singhurst 3024 (BAYLU); Cobb Cemetery, 12 Mar 1995, Singhurst 3024 (BAYLU); Cobb Cemetery, 12 Mar 1995, Singhurst 3025 (BAYLU); Ferguson Cemetery, off FR 937, ca. 2 miles NW of the Robertson Co. line, 12 Mar 1995, Singhurst 3020 (BAYLU). Milam Co.: Old Providence Cemetery, 20 Mar 1995, Singhurst 3201 (ASTC). Morris Co.: Daingerfield State Park, ca. 2.1 miles S of jct. of Tex. Hwy. 49 and park road, lawn area ca. $80 \mathrm{~m} \mathrm{NW}$ of activity center, $7 \mathrm{Mar}$ 1996, Singhurst 4801 (BAYLU). Navarro Co: Midway Cemetery, ca. 7 miles NE of Streetman, 18 Mar 1995, Singhurst 3028 (BAYLU). Rains Co.: Prospect Cemetery on County Road 1230 ca. 0.5 mile S of U.S. Hwy. 69, 6 Apr 1996, Stevens 209 \& Gooch (BAYLU). Red River Co.: McCrary Cemetery on FR 196 ca. 2 miles W of Tex. Hwy. 37, 5 Apr 1996, Stevens 198 \& Gooch (BAYLU). Robertson Co.: FR 979 at jet. with FR 2096 at Bald Prairie Cemetery, 98 m, 3 Mar 1995, Sievens 82, Gooch, \& Holmes (BAYLU); Seale Round Prairie Cemetery, off FR 937, ca. 2 miles SE of the Limestone Co. line, 12 Mar 1995, Singhurst 3022 (BAYLU). Rusk Co.: Martin Creek State Park, ca. 1.3 miles SW of jct. of FM 1716 and park road, lawn next to cabin no. 1, 5 Mar 1996, Singhurst 4804 (BAYLU). San Augustine Co.: Liberty Hill Baptist Church Cemetery, 2.3 miles $\mathrm{N}$ of Tex. Hwy. 21 by Tex. Hwy. 147, 16 Feb 1972, Thomas 27495 (NLU). Smith Co.: Tyler State Park, 0.6 mile W 
of jct. of FR 14 and park road, lawn S of registration office, 4 Mar 1996, Singhurst 4803 (BAYLU). Titus Co.: Winfield Cemetery on Interstate Hwy. $30 \mathrm{ca} .200 \mathrm{~m} \mathrm{E}$ of Spur 185, 5 Apr 1996, Stevens 201 \& Gooch (BAYLU). Upshur Co.: Cemetery on U.S. Hwy. 271 ca. 1 mile S of Camp Co. line, 5 Apr 1996, Stevens 204 \& Gooch (BAYLU). Van Zandt Co.: Purtis Creek State Recreation Area, at jct. of FM 316 and Gosham Road, 4 May 1995, Singhurst 3261 (BAYLU). Walker Co.: Huntsville State Park, jct. of Interstate Hwy. 45 and park road, ca. 1.9 miles SW of park road, N side of park road in lawn E of education center, 28 Feb 1996, Singhurst 4800 (BAYLU). Waller Co.: Macedonia Cemetery, E off of Macedonia School Road, $\mathrm{N}$ of Magnolia Road and S of Threemile Creek near the intersection of Harris, Walker and Montgomery cos., 19 Mar 1992, Brown 15832 (BAYLU (photo),SBSC). Wood Co.: Perryville Cemetery on FR 852 ca. 0.5 mile S of FR 1647, 5 Apr 1996, Stevens 205 \& Gooch (BAYLU).

\section{ACKNOWLEDGMENTS}

We wish to thank Larry E. Brown of SBSC for the loan of a specimen from Waller County, the Texas Parks and Wildlife Department for access to public lands under their jurisdiction, and the Beta Tau Chapter of Beta Beta Beta of Baylor University for partial financial support provided through a Bob Gardner Memorial research Grant to Stevens and Gooch.

\section{LITERATURE CITED}

Do, L.H., R.D. Gooch, J.R. Stevens, W.C. Holmes, \& J.R. Singhurst. 1996. New county records of Botrychium lunarioides in Texas. Amer. Fern J. 86:28-31.

Thomas, R.D. 1979. First record of Botrychium lunarioides and Ophioglossum nudicale var. tenerum (Ophioglossaceae) from Texas. The Southw. Naturalist 24:395-396.

Thomas, R.D., T. Briley, \& N. Carroll. 1981. Additional collections of Botrychium lunarioides from Texas and Oklahoma and comments on its dormancy. Phytologia 48:276-278.

Wagner, W.H. \& F.S. Wagner. 1993. In Flora of North America Editorial Committee, eds. Flora of North America, vol. 2, Pteridophytes and Gymnosperms. Oxford Press, New York, New York (Pp. 85-106). 


\section{$2 \mathrm{BHL}$ Biodiversity Heritage Library}

Gooch, R D et al. 1996. "Comments on the distribution of Botrychium lunarioides (Ophioglossaceae) in Texas." Phytologia 80, 280-283. https://doi.org/10.5962/bhl.part.15538.

View This Item Online: https://www.biodiversitylibrary.org/item/47108

DOI: https://doi.org/10.5962/bhl.part.15538

Permalink: https://www.biodiversitylibrary.org/partpdf/15538

\section{Holding Institution}

New York Botanical Garden, LuEsther T. Mertz Library

\section{Sponsored by}

The LuEsther T Mertz Library, the New York Botanical Garden

\section{Copyright \& Reuse}

Copyright Status: In copyright. Digitized with the permission of the rights holder.

Rights Holder: Phytologia

License: http://creativecommons.org/licenses/by-nc-sa/3.0/

Rights: https://biodiversitylibrary.org/permissions

This document was created from content at the Biodiversity Heritage Library, the world's largest open access digital library for biodiversity literature and archives. Visit BHL at https://www.biodiversitylibrary.org. 